\title{
RECENT TRENDS IN THE JURISPRUDENCE OF THE INTER- NATIONAL COURT OF JUSTICE AND INTERNATIONAL ARBITRAL TRIBUNALS, WITH SPECIAL REFERENCE TO TERRITORIAL AND BOUNDARY CASES ${ }^{*}$
}

\author{
Miyoshi Masahiro $^{* *}$
}

\section{INTRODUCTION}

Traditionally a clear distinction is made between judicial settlement and arbitration, with an emphasis on their functional differences. While such a distinction would have been reasonable as a matter of historical explanation of their separate functions, it seems a little too simplistic in view of their practice. Against this background, the present contribution will review the relationship between the International Court of Justice and international arbitral tribunals in the light of the territorial and boundary cases since the 1960s.

Broadly it may be said that the distinction dates back to the time of the establishment of the Permanent Court of International Justice (PCIJ). ${ }^{1}$ The Permanent Court was set up with the intention of doing away with what were thought to be the defects of arbitration, especially its voluntary and ad hoc nature. In that sense it was only natural to distinguish the new system from the traditional one. On the other hand, as the Permanent Court of Arbitration (PCA) had been in existence since 1899 and thus the institutionalisation of arbitration had made a little progress, there was a need to stress the difference between the PCA and the newly organized Permanent Court of International Justice. Throughout its existence the PCIJ accomplished a good deal, and it was succeeded by the International Court of Justice (ICJ) as the judicial arm of the United Nations Organisation. These developments would have contributed to the clear distinction of the PCIJ and ICJ from the traditional institution of

\footnotetext{
* This is a translation with some amendments of a paper presented at the autumn session of the Japanese Association of International Law in October, 1996. Grateful acknowledgement is made of the usual help of my colleague Professor JoHN HAMILTON in improving the English in my text.

"* Professor of International Law, Aichi University, Japan.

${ }^{1}$ As early as at the Hague Peace Conferences of 1899 and 1907 attempts were made to set up a permanent international court and make resort to arbitration compulsory. For a historic account of such attempts, see TAOKA RYOICHI, Kokusaiho III - Shinpan [International Law, Part III-New Edition] (1973)11-19. See also H.M. CORY, Compulsory Arbitration of International Disputes (1932)3-110; A.P. HIGGINS, The Hague Peace Conferences and Other International Conferences Concerning the Laws and Usages of War: Texts of Conventions with Commentaries (1909) 82-84; A.S. De BustamanTe, The World Court (trans. by ElizABETH F. READ, 1925) 41-67.
}

Asian Yearbook of International Law, Volume 6 (Ko Swan Sik et al., eds.

${ }^{\circ}$ Kluwer Law International; printed in the Netherlands), pp. 3-27 
arbitration, and consequently to the wide recognition of the newer institution being superior to the traditional.

Such recognition, however, was not shared by all states. The Permanent Court of Arbitration issued a circular note in 1960 with a view to urging its active use by states ${ }^{2}$ and the International Law Commission drafted the Model Rules on Arbitral Procedure in $1958,{ }^{3}$ while the declined use of the ICJ in the late 1960s and early 1970s drove the General Assembly of the United Nations to a discussion of ways and means to activate it. ${ }^{4}$ As part of such efforts the Rules of Court were amended in 1972 and 1978 to encourage the use of a Chamber as provided for in Article 26(2), of the Statute of the Court. ${ }^{5}$ A Chamber to be constituted under the amended Rules of Court, however, may be characterised as analogous to an arbitral tribunal.

There were other moves around the commemoration of the 50th anniversary of the founding of the ICJ. The British Institute of International and Comparative Law, for example, in March 1996 published the report of a study group on the ICJ's procedures and working methods, ${ }^{6}$ while in the field of arbitration the Permanent Court of Arbitration adopted a set of optional rules for arbitration in $1992^{7}$ and the Conference on Security and Cooperation in Europe (CSCE) adopted a Convention on Conciliation and Arbitration in $1993 .{ }^{8}$

The developments concerning review or improvement of judicial settlement and arbitration are significant. Reserving these for other studies, this contribution is limited to a comparison of recent judicial and arbitral decisions on territorial and boundary disputes with a view to showing that the two institutions have considerable common or analogous points in substantive aspects, if not in procedural aspects.

\footnotetext{
${ }^{2}$ PCA, Circular Note of the Secretary-General, 3 March 1960, 54 AJIL (1960) 940-941.

${ }^{3}$ UN Doc. A/CN.4/113, 3 March 1958, ILC Yearbook 1958-II p. 12.

${ }^{4}$ See e.g. UNGA Res. 2733 (XXV),15 December 1970: 'Review of the role of the International Court of Justice'. For a report on the comments of the member states on this question, see UN Doc.A/8382 and Adds.1-4: 'Report of the Secretary-General: review of the role of the International Court of Justice'.

${ }^{5}$ For a brief account of the amendments to the Rules of Court, see MIYOSHI MASAHIRO, 'Recent trends in international arbitration' (in Japanese), 113 Aichi Journal of Legal and Political Sciences (1987) 142-145. See also E. JIMÉNEZ DE ARÉCHAGA, 'The amendment to the rules of procedure of the International Court of Justice', 67 AJIL (1973) 1-22; G. GuYOMAR, Commentaire du Règlement de la Cour Internationale de Justice, Interprétation et Pratique (1973); D.W. BOWETT, 'Contemporary developments in legal techniques in the settlement of disputes', $180 \mathrm{RdC}$ (1983-II) 183.

${ }^{6}$ D.W. BowetT, J. Crawford, I. Sinclair, A.D. WATTS, 'The International Court of Justice: efficiency of procedures and working methods', (Report of the study group established by the British Institute of International and Comparative Law as a contribution to the UN Decade of International Law), 45 ICLQ Supplement S1-35 (1996).

7 PCA, 'Optional rules for arbitrating disputes between two states', 20 October 1992, 32 ILM (1993) 575-86.

${ }^{8}$ Convention on Conciliation and Arbitration within CSCE. Annex 2 to 'Decision on peaceful settlement of disputes of 15 December 1992, 32 ILM (1993) 557-68.
} 


\section{DIFFERENCES BETWEEN JUDICIAL SETTLEMENT AND ARBITRATION}

\subsection{Classical differentiations}

The basic idea of differentiating judicial settlement from arbitration would have been to signify the establishment of the Permanent Court of International Justice and emphasize its nature in contradistinction to the traditional method of arbitration. There used to be some arbitrations by tribunals without any arbitrators from third states as, for example, in the case of the Anglo-American arbitrations based on the Jay Treaty of $1794 .{ }^{9}$ Some arbitrations were even considered as another forum of diplomatic transactions. ${ }^{10}$ Many arbitral awards were not reasoned. ${ }^{11}$ The Hague Convention for the Pacific Settlement of International Disputes of 1899 for the first time included a clause that an award be reasoned, ${ }^{12}$ perhaps partly because the idea was beginning to prevail that an arbitral award should be reasoned. But it might also have shown a new idea of arbitration as it ought to be.

The main characteristics of arbitration, as compared with judicial settlement, would seem to be the parties' control over the composition of the tribunal and the process of its proceedings. ${ }^{13}$ They would be a reflection of the state's propensity for honour and insistence that it have as much control over its international relations as possible. In respect of the composition of the tribunal, whether an ad hoc tribunal or one of the Permanent Court of Arbitration, it is the states parties to the dispute that choose arbitrators. That such composition is problematical has been pointed out repeatedly, and as a way of improvement the PCIJ made its appearance. But this institution, and its successor also, still

\footnotetext{
${ }^{9}$ The Treaty of Amity, Commerce and Navigation between Great Britain and the United States of 19 November 1794, Arts. 5, 6 and 7. C. PARRY, 52 Consolidated Treaty Series 249, 250, 252. See also the 1903 Anglo-American Alaska Boundary arbitration in which the tribunal was composed of three arbitrators from each of the parties, 15 RIAA 481.

${ }^{10}$ In the Bay of Passamaquoddy Islands case of 1817 between Great Britain and the United States, the tribunal composed of one member from each of the parties determined the attribution of the islands. J.B. MOORE stated that the British commissioner had exhibited much ability and skill in his 'egotiations'with his American counterpart, while DE LAPRADELLE and POLITIS commented: "[la décision] n'est au fond, qu'une transaction . . . les deux commissaires n'ont pas toute l'impartialité désirable." J.B. MOORE, 6 International Adjudications, Modern Series (1936) 36; A. DE LAPRADELLE et N. POLITIS, 1 Recueil des Arbitrages Internationaux (1905) 304.

${ }^{11}$ E.g. the award of the British Guyana/Venezuela Boundary case of 1899 was not reasoned, 11 Proceedings of the Arbitration between the Government of Her Britannic Majesty and the United States of Venezuela: British Guyana-Venezuela Boundary (1899) 3237-3238. After handing down the award, the president of the tribunal stated that the rules of procedure used in this arbitration were mostly incorporated in the Hague Convention for the Pacific Settlement of International Disputes of 1899, ibid. 3238. Ironically, Art. 52 of the Convention provides: "La sentence, voté à la majorité des voix, est motivée." J.B. SCOTT (ed.), Texts of the Peace Conferences at The Hague, 1899 and 1907 (1908) 41.

${ }^{12}$ See supra $\mathrm{n} .11$.

${ }^{13}$ MIYOSHI, supra $\mathrm{n} .5$ at 133.
} 
has a problem in its 'national' judges or judges of the nationality of each of the parties. The control by the parties over the arbitral process is technically multifaceted. But, common to all aspects involved is the strong will of the parties to have such control. Thus, the parties are free to keep the oral proceedings or written pleadings closed, and they may even refrain from publishing the award. ${ }^{14}$

This tendency of arbitration shows its low degree of objectivity. But it is quite another matter whether improving its objectivity is possible or whether it can contribute to states going to court. Indeed experience suggests that states do not altogether prefer higher objectivity of arbitration. ${ }^{15}$ When, for example, the International Law Commission (ILC) requested governments for their comments on its draft Model Rules on Arbitral Procedure, their replies included a considerable number of critical comments that an arbitral tribunal should properly be composed of arbitrators chosen by the parties, and that the draft rules make light of the will of the parties in procedural matters. ${ }^{16}$ Likewise, the March 1960 Circular Note of the Secretary-General of the Permanent Court of Arbitration criticised the ILC's Model Rules on Arbitral Procedure for its provisions conflicting with the essential nature of arbitration that arbitrators are

${ }^{14}$ The Arbitration Agreement of 10 July 1975 for the 1977 Anglo-French Continental Shelf case, Art. 9(4), provides that "Any question of the subsequent publication of the proceedings shall be decided by agreement between the two Governments". 18 RIAA 6. The compromis of 12 March 1985 for the 1989 Guinea-Bissau/Senegal Maritime Boundary case, Art. 9(4), provides: "Les deux Gouvernements décident ou non de publier la sentence et/ou les pièces de procédure écrites ou orales." 20 RIAA 124.

${ }^{15}$ MIYOSHI MASAHIRO, 'The state's propensity for control over the settlement of disputes', 104 Aichi Journal of International Affairs (1996) 43-55.

${ }^{16}$ See, e.g., the reply of the Belgian government dated 13 March 1953 which stated that the ILC's draft articles, based on the idea of compulsory arbitration, would seem hardly acceptable if they were to secure the support of the majority of states, and that, according to the traditional concept of arbitration, the parties have the right to decide whether to submit a dispute to arbitration, to choose the arbitrators and to set the limits of the compromis. UN Doc. A/2456, 'Report of the International Law Commission to the General Assembly', ILC Yearbook 1953-II p.232. The Brazilian delegation to the United Nations, in its note verbal of 24 March 1953, pointed out that the draft articles apparently ignored the fact that an arbitral tribunal owes its existence to the will of the parties. Ibid. 233. In its reply dated 6 March 1953, the Indian government expressed its view that the idea of the ICJ being conferred compulsory jurisdiction by application of one of the parties without the consent of the other, in regard to the arbitrability of an existing dispute or the existence of an alleged dispute was unacceptable, and that the ruling principle of international arbitration was that there should be agreement of both parties, at least in the initial stages of the procedure. Ibid. 234. The Netherlands government, in its reply of 1 April 1953, with comparatively moderate criticism made a clear distinction between arbitration and judicial settlement and stressed the mediatory nature of arbitration as well as the 'prerogatives' of the parties in regard to both the composition of the tribunal and the course of the procedure. Ibid. 235. The British government, in its reply of 27 February 1953, presented the exceptional view of accepting the idea of compulsory arbitration as drafted by the ILC. The US delegation to the United Nations in its note verbal of 11 March 1953 simply acknowledged that the draft would have positive value as a statement of 'desired goals' in the field of arbitration. Ibid. 237, 238. 
chosen by the parties. The Note suggested that the existing procedures remain unchanged. ${ }^{17}$

In respect of the applicable law, the Statute of the PCIJ contained a clear provision on the application of international law, giving the impression that its applicable law was different from that of traditional arbitrations. The 1928 General Act for the Pacific Settlement of International Disputes provided for the three different methods of conciliation, judicial settlement and arbitration for different kinds of disputes. Following the General Act, the numerous bilateral treaties for the pacific settlement of disputes which were concluded in the next few years created a pattern of submitting legal disputes to judicial settlement and non-legal disputes to arbitration. ${ }^{18}$ This classification of disputes would seem to have led on to the idea that different applicable laws should be applied to different kinds of disputes. Such understanding would have reinforced the clear distinction of arbitration and judicial settlement.

\subsection{Comparison in the light of recent developments}

Recent arbitral awards in territorial and boundary cases tend to show that they are not very different in reasoning from ICJ Judgments in similar cases. Judge M. LACHS admitted the general tendency of "increasing assimilation of arbitration to adjudication" on the one hand. On the other hand he approved the revision of the ICJ Rules of Court in respect of the formation of Chambers under Article 26(2) of the Statute, by stating "[p]rovided that the judicial character of the proceedings is respected, I see little reason to spurn this injection into adjudication of some aspects of arbitral practice which States find attractive'. ${ }^{19}$ According to CHRISTINE GRAY and B. KINGSBURY, the substantive differences between arbitration and judicial settlement have become less precise..$^{20}$ This is

\footnotetext{
${ }^{17}$ Permanent Court of Arbitration, supra n. 2, at 940-1.

${ }_{18}$ See United Nations, Systematic Survey of Treaties for the Pacific Settlement of International Disputes 1928-1948, New York, 1949.

${ }^{19}$ M. LACHS, in A.H.A. SoONS (ed.), International Arbitration: Past and Prospects (1991) 41, as quoted in E. MCWHINNEY, 'International arbitration and international adjudication: the different contemporary lots of the two Hague Tribunals', Canadian Yearbook of International Law (1991) 406-407. The fact that one or two judges ad hoc were chosen to compose the Chambers in the Gulf of Maine, the Burkina Faso/Mali Frontier Dispute and the El Salvador/Honduras Land, Island and Maritime Frontier cases implies that the ICJ Chambers thus constituted are not different from arbitral tribunals. In the Sicula Electronics Company case of 1989 two sitting national judges joined the chamber.

${ }^{20}$ C. GRAY and B. KINGSBURY, 'Developments in dispute settlement: inter-state arbitration since 1945', 63 BYIL(1992) 98. In his dissenting opinion in the 1982 Tunisia/Libya Continental Shelf case, Judge GROS warned against the 'arbitralisation', as it were, of ICJ Chambers by saying that the Court must answer the request of states and declare the law, not attempt a conciliation by persuasion which does not belong to the Court's judicial role. ICJ Reports (1982) 156, para. 24. Before an ICJ Chamber, by its original objective, the parties are permitted to submit a single written pleading only (Art. 92(1) Rules of Court). But in fact this rule has not been observed in the Gulf of Maine, the Burkina Faso/Mali and the El Salvador/Honduras cases. Although in these cases
} 
shown, for example, in the fact that post-war compromis overwhelmingly refer to international law as the applicable law and that arbitral tribunals in cases where there was no express choice of law clause in the compromis have uniformly chosen to apply international law. ${ }^{21}$

GRAY and KINGSBURY also stated that there is no sign that states want to use arbitration mainly for non-legal disputes. Nor do arbitral tribunals seem prepared to avow openly that they will indulge in non-legal decision-making. ${ }^{22}$ There is no absolute contrast, they wrote, between judicial settlement and arbitration in respect of consideration for the parties. Some arbitral tribunals appear to have failed to successfully engage with both parties, as in the Japanese House Tax and Beagle Channel cases, while some ICJ Judgments, for instance in the North Sea Continental Shelf, Tunisia/Libya Continental Shelf and Burkina Faso/Mali Frontier Dispute cases have been notably successful in this regard. ${ }^{23}$ With respect to the question of diplomatic compromise as an alleged defect of the traditional arbitral practice,$^{24}$ the authors stated that some tendency towards compromise is inherent in any process of collective decision. They observed that " $[t]$ he Anglo-French Continental Shelf and Guinea/Guinea-Bissau maritime boundary arbitrations do not appear to involve more compromise or law-making than similar decisions of the ICJ". ${ }^{25} \mathrm{I}$ am entirely in agreement with these comments.

Thus, recent developments do not show marked differences between judicial settlement and arbitration. Yet they have not completely assimilated into each other: the parties' control over the composition of the tribunal and the various procedural aspects of the proceedings remains unchanged as essential to the nature of arbitration. It is in the applicable law that assimilation is relatively discernible. For example, since the 1969 North Sea Continental Shelf cases identified equitable principles as the applicable law in cases of maritime boundary delimitation, all subsequent similar cases, whether decided by the ICJ or arbitral tribunals, have spoken of equitable principles. They are, however, thought to be part of international law, and normally strictly distinguished from decisions ex aequo et bono.

more than one written pleading was filed in accordance with Art. 92(2) Rules of Court, the practice could be interpreted to point to the 'arbitralisation' of ICJ chambers.

${ }^{21}$ GRAY and KINGSBURY, ibid. at 103-104.

${ }^{22}$ Ibid. 105.

${ }^{23}$ Ibid. 115.

${ }^{24}$ W.C. DENNIS, 'Compromise - the great defect of arbitration', 11 Columbia Law Review (1911) 493-513.

${ }^{25}$ GRAY and KINGSBURY, loc. cit. n. 20 at 116. 


\section{THE WORLD COURT AND ARBITRAL AWARDS}

\subsection{Significance of reference to arbitral awards}

In international jurisprudence PCIJ and ICJ Judgments used to be thought to have higher authority, and placed on a higher level, than arbitral awards. ${ }^{26}$ Such grading would seem to hold basically true even today. ICJ Judgments are normally cited in subsequent cases and scholarly writings even though they were rendered in the absence of one of the parties or remain unfulfilled. ${ }^{27}$ In arbitrations instituted by agreement between the parties, no preliminary objection is made to the jurisdiction of the tribunal nor, generally, does one of the parties refuse to appear before the tribunal, ${ }^{28}$ as in some cases before the ICJ. But as it is composed ad hoc for each case, an arbitral tribunal cannot be expected to pay particular attention to consistency or continuity of jurisprudence. The lack of such a systematic accumulation of case law as the PCIJ and ICJ have, would be the weakest point of arbitration.

But the tendency towards undisputed supremacy of ICJ Judgments over arbitral awards in international jurisprudence appears to have faded away now. ${ }^{29}$ Indeed, the recent compromis submitting territorial and boundary disputes to arbitration mostly refer to international law as the applicable law, ${ }^{30}$ and there is little difference between the ICJ and arbitral tribunals in respect of the applicable law. Furthermore, as a matter of fact some arbitral awards are frequently referred to in recent ICJ Judgments. This tendency is worthy to note. Such reference, however, appears not only in Judgments of the Court but also, quite often, in individual opinions of judges and the parties' written pleadings and oral arguments. References by the latter mean they are intended to strengthen the quoting parties' arguments, and thus have less objectivity.

\footnotetext{
${ }^{26}$ According to HUGH THIRLWAY, former Secretary at the ICJ, at the time he entered the service of the Court in 1968, there was "an unwritten rule of drafting that the Court only referred specifically to its own jurisprudence, never to arbitral awards." See his "The law and procedure of the International Court of Justice 1960-1989: part two", 61 BYIL (1990) $128 \mathrm{n}$. 471. In a private conversation with Sir FRANCIS VALLAT in London on 2 July 1988, I was told that the ICJ never refers to arbitral awards.

${ }^{27}$ E.g. the Corfu Channel, Fisheries Jurisdiction, United States Diplomatic and Consular Staff in Teheran, Military and Paramilitary Activities in and against Nicaragua cases.

${ }^{28}$ In the 1970 Turriff Construction (Sudan) Ltd. v. Government of the Republic of the Sudan case, the Government refused to appear before the tribunal and the Government-nominated arbitrator stayed away from the proceedings, later to be replaced. 17 Nederlands Tijdschrift voor Internationaal Recht [Netherlands International Law Review] (1970) 200-222.

${ }^{29}$ THIRLWAY, immediately after the sentence quoted above in n. 26, stated: "[t]his rule appears now to have been abandoned." THIRLWAY, supra $\mathrm{n} .26$ at $128 \mathrm{n} .471$.

${ }^{30}$ A glance at ten compromis of arbitrations, from the Palena Boundary case of 1966 to the Mount Fitz Roy case of 1994, indicates that, except those for the Rann of Kutch and the Dubai/Sharjah Boundary cases, they provide for some form of international law as the basis of the decisions. In the Dubai/Sharjah case the award shows clearly that international law governed the case. See 91 ILR 678.
} 
What is important is the validity and persuasive power of the reasoning of individual arbitral awards. Perhaps the clincher would be what impact they can have on subsequent arbitral and ICJ decisions.

\subsection{Reference to arbitral awards by the ICJ}

There are some arbitral awards frequently referred to in ICJ Judgments. It is proposed here to identify what part(s) of such awards have been cited by the ICJ and how this was done. Some of these items are then taken up in the analysis that follows.

\subsubsection{Peaceful and continuous display of State authority}

The principle of effective occupation was clearly propounded as the basic principle of acquisition of territory by the Permanent Court of Arbitration in the 1928 Island of Palmas case. The applicable law providing this classical precedent of effective occupation was "the principles of internatonal law and any applicable treaty provisions". ${ }^{31}$ By highly legal reasoning, reputedly extremely careful and exemplary, the award states that:

"[t]itles of acquisition of territorial sovereignty in present-day international law are either based on an act of effective apprehension, such as occupation or conquest, or, like cession, presuppose that the ceding and the cessionary Powers or at least one of them, have the faculty of effectively disposing of the ceded territory."

Thus the award held that:

"the continuous and peaceful display of territorial sovereignty (peaceful in relation to other States) is as good as a title." 32

This principle purports that such an act of the state surpasses natural accretion, contiguity or discovery ${ }^{33}$ to constitute a title to acquisition of territorial sovereignty.

It is well known that the principle has since been quoted or cited in a good number of similar territorial cases. In the Legal Status of Eastern Greenland case of 1933, the earliest territorial case decided by the PCIJ after Island of Palmas, the Judgment stated:

"La prétention du Danemark ne s'appuie pas sur un acte d'occupation en particulier, mais invoque - pour se servir des mots qui figurent dans la sentence

\footnotetext{
${ }^{31}$ See the Preamble of the Special Agreement of 23 January 1925, 2 RIAA 831.

32 Ibid. 839.

${ }^{33}$ Ibid. 839, 854, 845.
} 
rendue le 4 avril 1928 par la Cour permanente d'Arbitrage dans l'affaire de l'île de Palmas - un titre résultant «d'un exercice pacifique et continu de l'autorité étatique sur l'île»." ${ }^{34}$

The PCIJ did not apply the principle at face value, but found that it was satisfied with very little in the way of the actual exercise of sovereign rights in the case of claims to sovereignty over areas in thinly populated or unsettled countries, such as Greenland, provided that the other state could not make out a superior claim. ${ }^{35}$ In one of the most recent cases, the Land, Island and Maritime Frontier Dispute case of 1992 between El Salvador and Honduras, the ICJ Chamber quoted the crucial passage of the Island of Palmas case to say that "the law of acquisition of territory invoked by El Salvador is, in principle, clearly established and buttressed by arbitral and judicial decisions." 36

In this connection a word is in order about the 1909 Grisbadarna case in which the conduct of the state in the sea area in question was appreciated. The compromis provided that "le Tribunal aura à fixer cette ligne frontière en tenant compte des circonstances de fait et des principes du droit international" ${ }^{37}$ Indeed the arbitral tribunal delimited the territorial sea boundary with due account taken of the 'circonstances de fait'. ${ }^{38}$ The important circumstance that was taken into account was the conduct of the state concerned, and it was significant that other states acquiesced in it. This case was referred to by the ICJ Chamber in its Judgment in the Gulf of Maine case of 1984, but the Chamber did so because the United States had extensively discussed this arbitral award in its pleadings. The Chamber found, however, that the issue of territorial sea boundary between Norway and Sweden was entirely different from that before it, and that even if the differences between the two cases were minimised, it was unable to conclude that the conduct of the United States was sufficiently clear, sustained and consistent to constitute acquiescence. ${ }^{39}$ In contrast to this negative evaluation of the Grisbadarna case by the Chamber in 1984, Judge AJIBOLA, in his separate opinion in the 1994 case of Territorial Dispute between Libya and Chad, positively evaluated the conduct of the state as discussed in the Grisbadarna case in relation to acquiescence. ${ }^{40}$

\footnotetext{
${ }^{34}$ PCIJ Publications, Series A/B No. 53 p. 45.

${ }^{35}$ Ibid. 46.

${ }^{36}$ ICJ Reports (1992) 563 para. 342. In the Libya/Chad Territorial Dispute case of 1994, Judge AJIBOLA in his separate opinion quotes this principle in emphasising the acquiescence of Spain and other countries. ICJ Reports (1994) 81 para. 109. In the same case Judge SETTE-CAMARA's dissenting opinion also refers to this principle. Ibid. 98.

${ }^{37} 11$ RIAA 153-4.

${ }^{38}$ Ibid. 161-162.

${ }^{39}$ ICJ Reports (1984) 309 para. 146.

${ }^{40}$ See supra n. 36.
} 


\subsubsection{Critical date}

The notion of the critical date is used to denote the date on which the fact or act in question has a critical meaning, the date of the commencement of the dispute, or even a certain period of time during which the critical situation is thought to have lasted. ${ }^{41}$ In the sense of a critical meaning the concept is said to have been used for the first time by MAX HUBER in his award in the Island of Palmas case. ${ }^{42}$ According to the award, as the island was ceded from Spain to the United States as a result of the peace treaty of 10 December 1898, the essential point was whether at the time of the conclusion of the treaty the island formed a part of Spanish or Netherlands territory. The time referred to was called the 'critical moment', rather than the critical date, while the origin of the dispute was found in the visit by General LEONARD WOOD, then Governor of the Province of Moro, to the island on 21 January $1906 .^{43}$

In the Legal Status of Eastern Greenland case, Denmark maintained that it had long established effective occupation there at the time of the alleged Norwegian occupation on 10 July 1931, whereas Norway argued that it had occupied a terra nullius on that date. ${ }^{44}$ Thus it was held that the critical date was that particular date, and that it was not necessary that Danish sovereignty over Greenland should have existed throughout the period preceding the date. Even if the material submitted to the Court were to be found insufficient to establish such sovereignty, the Court said, this would not exclude a finding that it was sufficient to establish a valid title in the period immediately preceding the Norwegian occupation. ${ }^{45}$ On this particular point, however, the Judgment failed to refer expressly to the Island of Palmas case.

It is well known that the critical date was extensively discussed in The Minquiers and Ecrehos case of 1953. In this case the point at issue was the date after which no subsequent acts of the parties had to be taken into account by the Court. France argued on the basis of the Anglo-French Convention on Fishery of 2 August 1839 that 1839 be the critical date, while the United Kingdom submitted that as the dispute had not 'crystallised' before the conclusion of the Special Agreement of 29 December 1950, this date should be considered as the critical date. ${ }^{46}$ The Court found that no dispute had arisen before 1886 and

\footnotetext{
${ }^{41}$ For a detailed discussion of the concept of the critical date, see G.G. FITZMAURICE, 'The law and procedure of the International Court of Justice, 1951-4: points of substantive law. Part II', 32 BYIL (1955-56) 20-44; D. BARDONNET, 'Les faits posterieurs à la date critique dans les différences territoriaux et frontaliers', Le Droit International au Service de la Paix, de la Justice et du Développement: Mélanges Michel Virally (1991) 53-78. The arbitral award in the 1966 Palena Frontier case states that the parties agreed that the critical date is not necessarily the same for all purposes. 16 RIAA 167.

${ }^{42}$ FITZMAURICE, ibid. at 21; R.Y. JENNINGS, The Acquisition of Territory in Inter-national Law (1963) 31.

${ }^{43} 2$ RIAA 843, 836.

${ }^{44}$ PCIJ Publications Series A/B No. 53 p. 44.

${ }^{45}$ Ibid. 45.

${ }^{46}$ ICJ Reports (1953) 59.
} 
1888, when France for the first time claimed sovereignty over the Ecrehos and the Minquiers respectively. But, in view of the "special circumstances of the present case", it held that "subsequent acts should also be considered by the Court, unless the measure in question was taken with a view to improving the legal position of the Party concerned". ${ }^{47}$ The idea that post-critical date acts should also be taken into account had been suggested in the Island of Palmas case before, ${ }^{48}$ but the Minquiers Judgment says nothing of this earlier case on this point. ${ }^{49}$

Other arbitral awards which discussed the critical date in one way or another include the 1966 Argentine-Chile Palena Frontier case, the 1977 Beagle Channel case, the 1981 Dubai-Sharjah Boundary case and the 1988 Location of Boundary Markers in Taba case between Egypt and Israel. ${ }^{50}$

\subsubsection{Uti possidetis}

The principle of uti possidetis was referred to in the Burkina Faso/Mali Frontier Dispute case of 1986 and the El Salvador/Honduras Land, Island and Maritime Frontier Dispute case of 1992, both decided by ICJ Chambers. The latter Decision quotes the 1933 arbitral award in the Honduras Borders case between Guatemala and Honduras in discussing uti possidetis. The ICJ Chamber, assuming that it should apply the principle of uti possidetis juris, according to which the new international boundaries follow the colonial administrative boundaries in Spanish America, states that the problem was to determine where those boundaries actually lay. ${ }^{51}$ Thus it quotes the arbitration of 1933 in which the task of the arbitrator was to determine the 'juridical line' of the 'uti possidetis of $1821^{\prime}$. But the quoted passage of the award conceded that, due to the lack of trustworthy information during colonial times, not only had the boundaries of jurisdiction not been fixed with precision, but also great areas had remained in which no effort had been made to assert any semblance of administrative authority. ${ }^{52}$ Consequently the Chamber referred to this award in a negative sense.

The principle of uti possidetis was discussed in more general terms, but without reference to any earlier arbitral award dealing with it, in the Burkina Faso/Mali Frontier Dispute case. The ICJ Chamber was expressly requested to

\footnotetext{
${ }^{47}$ Ibid.

${ }^{48}$ The arbitrator found that there could not be any question of ruling out the events of the period 1898-1906. 2 RIAA 866.

${ }^{49}$ In the 1975 Western Sahara case, one of the questions on which the Court was requested to give an advisory opinion was whether Western Sahara was terra nullius at the time of its colonisation by Spain. ICJ Reports (1975) p. 14, para. 1. But the Court held that it was not concerned to establish the critical date in the sense given to this term in territorial disputes. Ibid. 38 para. 76.

${ }^{50}$ Palena Frontier case, 16 RIAA 166; Beagle Channel case, 52 ILR 93; Dubai/Sharjah case, 91 ILR 590-4; Taba case, 20 RIAA 45. In the Taba case the tribunal called the entire period of the mandate (29 September 1923 to 14 May 1948) "the critical period". Award, para. 172.

${ }^{51}$ ICJ Reports (1992) 380 para. 28.

52 RIAA 1325.
} 
resolve the dispute on the basis of the "principe de l'intangibilité des frontières héritées de la colonisation", ${ }^{53}$ and felt unable to disregard the principle of uti possidetis juris since its application precisely gives rise to respect for the 'frontières héritées' ${ }^{54}$ According to the Chamber, the principle is not a special rule peculiar to the Spanish-American system of international law under which it was borne, but a principle of general scope which prevents the independence and stability of new states from being endangered by fratricidal struggles provoked by the challenging of frontiers following the withdrawal of the administering power. ${ }^{55}$ In other words, the fact of the new African states respecting the boundaries established by the colonial powers must be seen, in the opinion of the Chamber, as the application of a general rule in Africa ${ }^{56}$ Thus, the Chamber places this principle among the most important legal principles and yet makes no express reference to earlier arbitral awards dealing with it, notably the Honduras Borders case of 1933 in which the tribunal fully discussed the principle of Latin American origin.

In the 1994 Libya/Chad Territorial Dispute case, Judge AJIBOLA developed an extensive discussion of uti possidetis in Section VII of his separate opinion, where he quotes a passage at the outset of the arbitral award in the Colombia/Venezuela Frontiers case of 1922 that discusses the 'uti possidetis juris of 1810 '. ${ }^{57}$ The Swiss Federal Council, as the arbitrator, shows a very clear picture of the principle ${ }^{58}$ in its strictly legal treatment of the case.

\subsubsection{Natural prolongation or appurtenance}

The North Sea Continental Shelf cases of 1969, in defining the concept of continental shelf as the basis for its delimitation, determined it to be the seabed and its subsoil as a natural prolongation of the land territory of the coastal State. ${ }^{59}$ In another part of the Judgment the same idea was expressed by the principle that 'the land dominates the sea' ${ }^{60}$ The ICJ Judgment did not mention a precedent in its development of the concept, but the same Court had this to say in the Anglo-Norwegian Fisheries case of 1951:

\footnotetext{
${ }_{53}^{53}$ See Preamble of the compromis of 16 September 1983. ICJ Reports (1986) 557.

${ }^{54}$ Ibid. 565 para. 20.

${ }^{55}$ Ibid.

${ }^{56}$ Ibid. 565 para. 21.

${ }^{57}$ ICJ Reports (1994) 84-85 para. 118.

${ }^{58} 1$ RIAA 228.

${ }^{59}$ ICJ Reports (1969) 22 para. 19. For a comment on this point, see R.Y. JENNINGS, 'The limits of continental shelf jurisdiction: some possible implications of the North Sea Case Judgment', 18 ICLQ (1969) 821-823, which sets store by the relevant clause of President TRUMAN's Proclamation of 28 September 1945 and Art. 2 of the Convention on the Continental Shelf of 1958 which gives another expression to it.

${ }^{60}$ ICJ Reports (1969) 51 para. 96. In the 1978 Aegean Sea Continental Shelf (Jurisdiction) case, the ICJ, on the basis of the North Sea cases, stated that "legally a coastal State's rights over the continental shelf are both appurtenant to and directly derived from the State's sovereignty over the territory abutting on that continental shelf". ICJ Reports (1978) 36 para. 86.
} 
“. . . il faut signaler de façon générale l'étroite dépendence de la mer territoriale à l'égard du domaine terrestre. C'est la terre qui confère à l'État riverain un droit sur les eaux qui baignent ses côtes." 61

"[La laisse de basse mer] est le plus favorable à l'État côtier et met en evidence le caractère des eaux territoriales comme accessoire du territoire terrestre."

Here what was being considered was the territorial sea, and not the continental shelf, but the underlying idea would be the same. However, no reference was made to a precedent on this point either.

The concept of appurtenance was clearly expounded long before in the arbitral award in the Grisbadarna case of 1909:

"principes fondamentaux du droit des gens, tant ancien que moderne, d'après lesquels le territoire maritime est une dépendance nécessaire d'un territoire terrestre". ${ }^{63}$

For unknown reasons this precedent has not been referred to in subsequent cases. Perhaps the concept had already been established as such a commonality at the time of the Fisheries case that it required no citation of a precedent, or else it might have been due to the unwritten law of the ICJ that it only refer to its own jurisprudence and never to arbitral awards. ${ }^{64}$

Attention may now be turned to the relationship between the doctrine of natural prolongation and delimitation of the continental shelf. The North Sea cases Judgement stated expressly in its operative part:
"delimitation is to be effected ... in such a way as to leave as much as possible to each Party all those parts of the continental shelf that constitute a natural prolongation of its land territory into and under the sea, without encroachment on the natural prolongation of the land territory of the other. ${ }^{65}$

That pronouncement would appear to give the impression that natural prolongation has a direct link to delimitation. If the North Sea cases presented an 'absolutist' doctrine of natural prolongation, the 1977 arbitral award in the $A n$ glo-French Continental Shelf case slightly revised the doctrine. Referring to the North Sea cases on this point, the arbitral award stated: "[s]o far as delimitation is concerned, however, this conclusion states the problem rather than solves it". ${ }^{66}$ It pronounced first in general terms:

"[I]t is clear both from the insertion of the 'special circumstances' provision in Article 6 and from the emphasis on 'equitable principles' in customary law that

\footnotetext{
${ }^{61}$ ICJ Reports (1951) 133.

${ }^{62}$ Ibid. 128.

${ }^{63} 11$ RIAA 159.

${ }^{64}$ See supra $\mathrm{n} .26$.

${ }^{65}$ ICJ Reports (1969) 53 para. 101(c)(1).

${ }^{66} 18$ RIAA 49 para. 79.
} 
the cardinal principle of 'natural prolongation of territory' is not absolute, but may be subject to qualification in particular situations."67

It then went on to say that "[t]he application of that principle [i.e. of natural prolongation] . . . has to be appreciated in the light of all the relevant geographical and other circumstances" and that "the effect to be given to the principle of natural prolongation of the coastal State's land territory is always dependent not only on the particular geographical and other circumstances but also on any relevant considerations of law and equity". ${ }^{68}$

It is with this logic that the award concludes that a physical feature called Hurd Deep-Hurd Deep Fault Zone in the English Channel should not be considered as a gap in the natural prolongation of the land territory. It adds, importantly, that "to attach critical significance to . . . the Hurd Deep-Hurd Deep Fault Zone in delimiting the continental shelf boundary . . . would run counter to the whole tendency of State practice on the continental shelf in recent years" ${ }^{69}$ Thus the arbitral tribunal took a 'relativist' position on the doctrine of natural prolongation.

The Tunisia/Libya Continental Shelf case of 1982 referred to the Hurd Deep as a precedent ${ }^{70}$ in turning down the argments of natural prolongation and geology which the parties developed most elaborately. ${ }^{71}$ The Hurd Deep was also referred to in the Gulf of Maine case of $1984 .^{72}$ It would be another instance of the impact of the Hurd Deep that the rift zone which Libya claimed to be a major feature was rejected as a relevant factor to be taken into account in delimitation in the Libya/Malta Continental Shelf case of $1985 .{ }^{73}$

\subsubsection{Customary law of maritime boundary delimitation}

The North Sea cases of 1969 showed that the customary law of continental shelf delimitation is that "delimitation is to be effected by agreement in accordance with equitable principles, and taking account of all the relevant circumstances . . ." ${ }^{74}$ The Anglo-French Continental Shelf case of 1977 contributed to the further elaboration of this law. The Court of Arbitration made an effort to fuse, as it were, the mentioned customary law and the delimitation rule as provided for in the 1958 Convention on the Continental Shelf into one. Its award stated on this point:

\footnotetext{
${ }^{67}$ Ibid. 91 para. 191.

${ }^{68}$ Ibid. 92 para. 194.

${ }^{69}$ Ibid. 60 para. 107. The Court of Arbitration also took into account the fact that the United Kingdom had agreed to the drawing of a median line between it and Norway in disregard of the Norwegian trough in the 1960 s.

${ }^{70}$ ICJ Reports (1982) 57 para. 66.

${ }^{71}$ Ibid. 43-47 paras. 38-44; 50-54 paras. 52-61.

${ }^{72}$ ICJ Reports (1984) 274 para. 46.

${ }^{73}$ ICJ Reports (1985) 34-7 paras. 35-41.

${ }^{74}$ ICJ Reports (1969) 53 para. 101(c)(1).
} 
"[T]he rôle of the 'special circumstances' condition in Article 6 is to ensure an equitable delimitation; and the combined 'equidistance-special circumstances rule', in effect, gives particular expression to a general norm that, failing agreement, the boundary between States abutting on the same continental shelf is to be determined on equitable principles." 75

The 'combined rule' thus enunciated was later quoted in the Gulf of Maine case of 1984 as confirming the formula of customary law of the North Sea cases. ${ }^{76}$ The quoted passage of the Anglo-French case award was further quoted as a 'much-quoted passage' in the Greenland/Jan Mayen Maritime Delimitation case of $1993 .{ }^{77}$

It is interesting to note that the Gulf of Maine case was concerned not only with the continental shelf but also the fisheries zone, and that the ICJ Chamber was requested to draw a single line of delimitation common to the two regimes. It is of great significance that the Chamber thought the 'combined rule' to be the guiding principle in determining the single boundary line with primary account taken of the geographical factors. The Libya/Malta Continental Shelf case, in which the ICJ was requested to decide on the continental shelf only, found that the principles and rules underlying the concept of the exclusive economic zone could not be left out of consideration, that the two institutions were linked together in modern law and consequently that greater importance must be attributed to elements, such as distance from the coast, which are common to both concepts. ${ }^{78}$ Subsequently, the Greenland/Jan Mayen case of 1993 quoted the relevant passage of the Libya/Malta case Judgment in its entirety, ${ }^{79}$ thus indirectly appreciating the formula of the Anglo-French award.

Another point of interest about the formation of customary law of maritime boundary delimitation is the fact that reference is made to the contribution of unspecified arbitral awards. In its context of reviewing the concept of 'relevant circumstances' in comparison with customary law and the provisions of Article 6 of the Convention on the Continental Shelf, the ICJ Judgment in the Greenland/Jan Mayen case states: "General international law, as it has developed through the case-law of the Court and arbitral jurisprudence, and through the work of the Third United Nations Conference on the Law of the Sea, has employed the concept of 'relevant circumstances'. This concept can be described as a fact necessary to be taken into account in the delimitation process" ${ }^{80} \mathrm{Ar}$ bitral jurisprudence is thus duly appreciated along with the ICJ case-law and the work of UNCLOS-III. ${ }^{81}$

\footnotetext{
75 18 RIAA 45 para. 70.

${ }^{76}$ ICJ Reports (1984) 293 para. 92.

${ }^{77}$ ICJ Reports (1993) 58 para. 46.

${ }^{78}$ ICJ Reports (1985) 33 para. 33.

${ }^{79}$ ICJ Reports (1993) 58-9 para. 46.

${ }^{80}$ Ibid. 62, para. 55 .

${ }^{81}$ Judge MOSLER made a statement of similar effect in his dissenting opinion in the Libya/Malta case. He mentioned 40 years of development of international law regarding delimitation of
} 


\subsubsection{Legal status of islands}

In the Anglo-French case the size and importance of the Channel Islands was a point at issue. They were in the end accorded an enclave of continental shelf area on the French side of the continental shelf divided by a median line. ${ }^{82}$ In the Libya/Malta case this treatment of the Channel Islands was compared with the legal status of the island State of Malta. Apart from its very small size as compared with that of Libya, Malta was assumed to have a continental shelf area on the basis of its legal status as an independent State. ${ }^{83}$

Again in the Anglo-French case the status of the Scilly Isles was discussed extensively. In view of the relationship between their distance from the mainland and that of Île d'Ouessant off the French mainland, a 'half-effect' was accorded to the Scillies based on considerations of equity. ${ }^{84}$ This method of giving partial effect to islands of a State depending on their location, in the delimitation of maritime boundaries was later considered as a precedent for the half-effect to be accorded to the Kerkennah Islands in the Tunisia/Libya case of 1982 and to Seal Island in the Gulf of Maine case of $1984 .{ }^{85}$ The method was further quoted in the Greenland/Jan Mayen case of 1993 as a precedent for first drawing a provisional median line and then adjusting it in the light of special circumstances ${ }^{86}$ The logic of the ICJ was that the existence of the Scilly Isles in the Anglo-French case was the special circumstance justifying the adjustment or shifting of a median line provisionally adopted.

\subsubsection{Proportionality}

In the North Sea cases it was found that equity requires that in the delimitation of continental shelf boundaries there be a reasonable degree of proportionality between the extent of the continental shelf appertaining to the coastal states and the lengths of their respective coastlines ${ }^{87}$ This principle has been applied in all subsequent cases of maritime boundary delimitation. But in the AngloFrench case the principle was constituted in the opposite way: an important consideration was how disproportion should be corrected. The award stated:

\footnotetext{
maritime areas, and stated that further detailed developments must be left to the case-law, "not forgetting the arbitrations between France and Great Britain in 1977 and . . . between GuineaBissau and Guinea in 1985". ICJ Reports (1985) 114.

${ }^{82} 18$ RIAA 88, 89-90 paras. 184 and 187.

${ }^{83}$ ICJ Reports (1985) 42 paras 52-3.

${ }^{84} 18$ RIAA 116 para. 249. This finding of the Court of Arbitration was based on the practice of States which includes some instances of partial effect, and especially one precedent of half effect. This, however, is not identified in the award. Ibid. 117 para. 251. For a discussion of this point, see MIYOSHI MASAHIRO, 'The arbitration on the delimitation of the continental shelf in the English Channel' [in Japanese], 87 Aichi Journal of Legal and Political Sciences (1978) 146 n. 10.

${ }^{85}$ ICJ Reports (1982) 89 para. 129; ICJ Reports (1984) 337 para. 222.

${ }^{86}$ ICJ Reports (1993) 61 para. 51.

${ }^{87}$ ICJ Reports (1969) 52 para. 98.
} 
"In short, it is disproportion rather than any general principle of proportionality which is the relevant criterion or factor. . . . [I]t is rather a question of remedying the disproportionality and inequitable effect produced by particular geographical configurations or features in situations where otherwise the appurtenance of roughly comparable attributions of continental shelf to each State would be indicated by the geographical facts." 88

This principle of proportionality as expressed conversely was employed in the Gulf of Maine case without reference to its being the formula of the AngloFrench case. ${ }^{89}$ By contrast, the relevant passage of the arbitral award was quoted in its entirety in the Libya/Malta case, ${ }^{90}$ where the conclusion was that "there is certainly no evident disproportion in the areas of shelf attributed to each of the Parties respectively such that it could be said that the requirements of the test of proportionality as an aspect of equity were not satisfied". ${ }^{91}$ Again in the Greenland/Jan Mayen case the earlier cases of proportionality, including this conversely expressed principle, were quoted briefly but exhaustively. ${ }^{92}$

\subsubsection{Obligation to negotiate in good faith}

That negotiations between the parties to a dispute must be conducted in good faith has been pointed out time and again. The North Sea cases, for example, discussed the obligation of the parties to negotiate as far as possible with a view to arriving at an agreement, by referring to the PCIJ Advisory Opinion in the Railway Traffic between Lithuania and Poland case of 1931. ${ }^{93}$ The Advisory Opinion, while discussing the obligation to negotiate, did not require the obligation to reach agreement. ${ }^{94}$ But some years before in the Chile/Peru Tacna-Arica case of 1925, the arbitral award had already held that whilst good faith in negotiations was important, it was not illegal if the parties failed to agree in the end:

\footnotetext{
"The question now presented is not whether the particular views, proposals, arguments and objections of either Party during the course of the negotiations should be approved, but as to the good faith with which these views, proposals, arguments and objections were advanced. The failure to agree upon a special protocol fixing the conditions of the plebiscite cannot therefore be regarded as being in itself a breach of the treaty." 95
}

\footnotetext{
${ }^{88} 18$ RIAA 58 para. 101.

${ }^{89}$ ICJ Reports (1984) 323 para. 185.

${ }^{90}$ ICJ Reports (1985) $44-45$ para. 57.

${ }^{91}$ Ibid. 55 para. 75.

${ }_{92}$ ICJ Reports (1993) 67-8 para. 66. See also ibid. 68-9 paras. 67-70.

${ }^{93}$ ICJ Reports (1969) 47-48 para. 87.
}

${ }^{94}$ PCIJ Publications, Series A/B No. 42, p. 116, where the Permanent Court said: "Mais l'engagement de négocier n'implique pas celui de s'entendre et notamment il n'en résulte pas pour la Lithuanie l'engagement et, en conséquence, l'obligation de conclure les accords administratifs et techniques indispensables pour le rétablissement du trafic sur la section de ligne de chemin de fer Landwarów-Kaisiadorys".

${ }^{95} 2$ RIAA 933. 
The same logic was used in the Lac Lanoux arbitration of 1957. The award affirmed the necessity of prior notification, but denied the obligation to secure the other party's agreement which would amount to the right of veto. ${ }^{96}$

Thus the obligation to negotiate in good faith, as developed in the Lac Lanoux and North Sea cases was referred to by Judge GROS in his dissenting opinion in the Tunisia/Libya case of $1982 .{ }^{97}$

\section{DECISIONS EX AEQUO ET BONO}

Over a long period of time there were very few cases in which the PCIJ or ICJ and arbitral tribunals decided expressly ex aequo et bono. However, a number of judicial and arbitral cases, especially in the sphere of maritime boundary delimitation, have been decided by the application of equity since the North Sea cases of 1969. Although in this contribution the examination of equitable cases is not specifically intended, it is proposed here to include some of such cases which might be suspected of having been decided ex aequo et bono.

\subsection{Judicial cases}

Among the cases decided by the PCIJ and ICJ there is none that has been clearly decided ex aequo et bono. But a few cases have been criticised for allegedly deciding ex aequo et bono. A case in point is the North Sea cases. In this first-ever case of continental shelf delimitation, Denmark and the Netherlands argued in favour of the application of the equidistance principle as laid down in the 1958 Convention on the Continental Shelf, while the Federal Republic of Germany as a non-party to the Convention asserted that 'just and equitable share' be the guiding principle. The Court rejected both contentions on the grounds that the first was not a customary rule of international law and that the second relied on the theory of distributive justice, and instead preached in favour of the application of equitable principles. In discussing equity, the Court maintained that distributive justice, which means attribution, was foreign to delimitation which means the identification of the boundary line between the overlapping continental shelf areas of coastal States. But it might be doubted whether the Court's Judgment did not involve any idea of distribution. For example, in its finding that given the comparable lengths of the coastlines of the three countries, the area of the continental shelf which accrues to Germany by the application of the equidistance principle would be unduly small in the light

\footnotetext{
${ }^{96}$ The arbitral award states: "De toute façon, l'obligation de donner l'avis préalable ne renfermer pas celle, beaucoup plus étendue, d'obtenir l'accord de l'Etat avisé; le but de l'avis peut être tout autre que celui de consentir à [l'Etat] B l'exercise du droit de veto . . .”. 12 RIAA 309.

${ }^{97}$ GROS stated: "Il n'y a pas de négociation, si chaque Partie, ou l'une d'elles, insiste sur sa propre position sans jamais envisager d'atténuation ou de modification." ICJ Reports (1982) 145 para. 4.
} 
of the proportionality principle, there could be an indication that the Court might have taken distributive justice into account. Thus criticism could arise that such a consideration or finding is one ex aequo et bono or extraneous to the framework of law. ${ }^{98}$

It was found in the Tunisa/Libya case of 1982 that equitable principles are those which produce equitable results. ${ }^{99}$ If that is so, it is hard to see how the application of equitable principles is distinguished from a decision ex aequo et bono which is also intended to provide an equitable solution. ${ }^{100}$ In the Libya/Malta case of 1985, the Court held that in light of the great difference in the lengths of the coastlines of the parties, it was equitable to attribute a much larger continental shelf area to Libya by transposing the provisionally determined median line towards Malta through $18^{\prime}$ of latitude. ${ }^{101}$ Here a suspicion may arise that a consideration of proportionality did in fact mean a distribution of the continental shelf, a case of deciding ex aequo et bono. Furthermore, the Court's Judgement that it was justified to 'attribute' a larger shelf area to Libya in view of the great difference in length between the coasts of the two countries $^{102}$ conflicts with its own strong denial in the North Sea cases that delimitation included attribution of a shelf area. Still another point that is hard to understand is how the idea of shifting the provisional dividing line through 18', rather than say 10', of latitude may be justified. What is the right basis of calculation of $18^{\prime}$, rather than $10^{\prime}$, for the distance of transposition? How can it be claimed to be different from the past arbitral decisions ex aequo et bono in the estimation of damages or the calculation of the rate of interest on the damages?

A somewhat similar suspicion may be raised with regard to the Court's finding in the Greenland/Jan Mayen case. It would suffice here to refer to the individual opinions of three judges. In his separate opinion Judge ODA admitted that the Court's choice of "the line . . cannot be categorized as mistaken because it represents one choice from an infinite number of potential lines of delimitation in this area", but "venture[d] to suggest that it was drawn in an arbitrary manner, unsupported by any sufficiently profound analysis". ${ }^{103}$ Judge

\footnotetext{
${ }^{98}$ See W. FrIEDMANN, 'The North Sea Continental Shelf cases - a critique', 64 AJIL (1970) 236: "But what can scarcely be doubted is that, by rejecting the criteria laid down in the convention and other documents, the Court, in effect, was giving a decision ex aequo et bono, under the guise of interpretation. The Court applied a kind of distributive justice while denying that it was doing so."

${ }^{99}$ The ICJ Judgment stated: "It is, however, the result which is predominant; the principles are subordinate to the goal. The equitableness of a principle must be assessed in the light of its usefulness for the purpose of arriving at an equitable result. It is not every such principle which is in itself equitable; it may acquire this quality by reference to the equitableness of the solution." ICJ Reports (1982) 59 para. 70.

${ }^{100}$ See MIYOSHI MASAHIRO, Considerations of Equity in the Settlement of Territorial and Boundary Disputes (1993) 192.

${ }^{101}$ ICJ Reports (1985) 52 para. 73.

${ }^{102}$ ICJ Reports (1985) 50 para. 68, where the Court stated: "In the view of the Court, this difference is so great as to justify the adjustment of the median line so as to attribute a larger shelf area to Libya . .." (emphasis added).

${ }^{103}$ Emphasis in original. ICJ Reports (1993) 117 para. 100.
} 
SCHWEBEL in his separate opinion commented that "the Court by this holding of distributive justice has departed from the accepted law of the matter, as fashioned pre-eminently by it". ${ }^{104}$ Judge SHAHABUDDEEN in his separate opinion stated that "the equitable principles which the Court applies lack concreteness to the point where the Court is in fact exercising a range of discretion which is practically indistinguishable from a power to decide ex aequo et bono". 105

In this connection an intriguing comment made by a former judge of the International Court of Justice may be quoted. In his private letter addressed to ELIHU LAUTERPACHT in May 1978, Sir GERALD FITZMAURICE is said to have made some observations on LAUTERPACHT's critical comments on the way equitable principles were applied in the North Sea and Anglo-French cases, by confiding that:

\footnotetext{
"where . . . the Tribunal is precluded by its Statute or terms of reference from deciding ex aequo et bono, but is in fact doing just that, it cannot avow it, and has to take refuge in silence." 106
}

\subsection{Arbitral jurisprudence}

\subsubsection{Claims cases}

When discussing a decision ex aequo et bono, one cannot afford to ignore a considerable number of claims cases which have been decided on that basis. But since this contribution is intended to discuss territorial and boundary cases, it is proposed here to take up just a few claims cases. There are not so many compromis using the formula of ex aequo et bono as such, but arbitrations applying this basis of decision abound besides those which, while they were to be decided on the basis of, say 'absolute equity' or 'law and equity', would in fact have been decided ex aequo et bono.

A decision ex aequo et bono was made in the Death of James Pugh case of 1933 in accordance with the provisions to that effect in the compromis. On 30 June 1929 JAMES PUGH, an Irish seaman who had been drinking heavily for some hours in Colon in Panama, resisted arrest and was clubbed to death by the police. The arbitrator found that the clubbing was not in excess of the lawful discharge of police duties under the prevailing circumstances, and dismissed the claim of the British Government against the Government of Panama ${ }^{107} \mathrm{He}$ acted under Article 3 of the compromis, "taking into consideration solely for

\footnotetext{
${ }^{104}$ Ibid. 120.

${ }^{105}$ Ibid. 193.

${ }^{106}$ Emphasis Sir GeRALD FITZMAURICE's. E. LAUTERPACHT, Aspects of the Administration of International Justice (1991) 125 n. 19.

107 3 RIAA 1441-53.
} 
the finding of the facts the proofs which with regard thereto are to be found in the record, [to] decide ex aequo et bono on the questions". ${ }^{108}$

In the 1931 Campbell case, Major CAMPBELL by a signed document declared on 5 December 1912 that he abandoned his lease of a mining concession in Mozambique in favour of its legitimate owners without right to any indemnity, and the Government of Portugal consented in 1912 to indemnify CAMPBELl for damage suffered. The arbitrator was asked to decide on the effect of the declared abandonment and on the amount of indemnity if any was due. The compromis provided for "a speedy settlement of the question in accordance with the principles of law and equity". ${ }^{109}$ But in the arbitrator's reasoning the calculation of the indemnity was shown to be made ex aequo et bono. ${ }^{110}$

In the Tinoco arbitration of 1923 the basis of decision was "existing Agreements, the principles of Public and International Law", ${ }^{111}$ but the single arbitrator thought himself justified in proceeding ex aequo et bono, at least in part, and held that:

"the [Royal Bank] is subrogated to the title of Costa Rica in the mortgage and
that . . Costa Rica should transfer and assign the mortgage to the bank for its
benefit, together with any interest which may have been meantime collected
thereon."112

The arbitral tribunal in the Norwegian Shipowners' Claims case of 1922 was to proceed "in accordance with the principles of law and equity". ${ }^{113}$ But in a section of the award, the tribunal discussed "The Law Governing the Arbitration" and stated that "[t]he words 'law and equity' . . . can not be understood in the traditional sense in which they are used in Anglo-Saxon jurisprudence" but rather mean "general principles of justice as distinguished from any particular system of jurisprudence or the municipal law of any State". In the view of the tribunal, the majority of international lawyers seem to agree on this understanding of the formula. ${ }^{114}$ Thus the tribunal proceeded to assess the amount of compensation and interest ex aequo et bono. ${ }^{115}$

In the series of protocols of agreement of 1903 instituting claims of ten Euro-American States against Venezuela, the basis of decision was 'absolute equity', ${ }^{116}$ but the arbitrations, at least in part, proceeded on a basis which is

\footnotetext{
${ }^{108}$ Ibid. 1442.

${ }^{109}$ See Preamble of the 'Compromis d'arbitrage concernant les réclamations du Major Campbell' of 1 August 1930, para. 4, 2 RIAA 1147.

${ }^{110}$ Ibid. 1157.

${ }^{111}$ Art. 1 of the compromis of 12 January 1922, 1 RIAA 372.

${ }^{112}$ Ibid. 395.

${ }^{113}$ Art. 1 of the compromis of 30 June 1921, 1 RIAA 310.

${ }^{114}$ Ibid. 331.

${ }^{115}$ Ibid. 339, 340, 341.

${ }^{116}$ Art. 1 of the Protocol of Agreement between the United States and Venezuela of 17 February 1903 , the earliest of ten such protocols: "The commissioners, or, in case of their disagreement, the
} 
hard to be distinguished from deciding ex aequo et bono. For example, in the British-Venezuelan mixed claims commission, the umpire had this to say in his award:

"The phrase 'absolute equity' used in the protocols the umpire understands and interprets to mean equity unrestrained by any artificial rules in its application to the given case." 117

\subsubsection{Territorial and boundary cases}

Among the cases of territorial and boundary disputes the Chaco case of 1938 is the one of which the compromis expressly referred to ex aequo et bono. Article 2 provided that the boundary line should be determined by the Presidents of Argentina, Brazil, Chile, the United States, Peru and Uruguay "en leur qualité d'arbitres selon l'équité, lesquels, agissant ex aequo et bono, formuleront leur décision arbitrale conformément à la présente clause et aux clauses ci-après. ${ }^{118}$ The arbitrators acted on this basis of decision, and said that the decided boundary was equitable. The compromis in this case was, however, the Bolivia-Paraguay Peace Treaty, and the arbitration accordingly was an aspect of the post-bellum adjustment between the two countries involving considerations of peace and security. ${ }^{119}$

Similarly, a cease-fire agreement constituted the compromis for the 1968 Rann of Kutch case. The tribunal was directed under the agreement to act "in the light of [the parties] respective claims and evidence produced before it" ${ }^{120}$ During the meetings of the tribunal in February 1966 the question arose whether it had the power to decide ex aequo et bono. After hearing the parties on this issue the tribunal decided that, as both parties pointed out, equity forms part of international law and therefore the parties were free to present and develop their cases with reliance on principles of equity. As the compromis did not authorize the tribunal clearly and beyond doubt to decide ex aequo et bono and the parties had not consented by any subsequent agreement to confer it the power to do so, the tribunal resolved that it had no such power. ${ }^{121}$ Based on this understanding of the applicable law, the tribunal carefully proceeded to examine the huge volume of evidence presented by the parties. In the last part of the decision, or the opinion of the chairman of the tribunal in which the arbitrator nominated by Pakistan concurred, the two deep inlets on either side of Nagar Parkar (a peninsula-shaped Pakistani territory jutting into the Indian ter-

umpire, shall decide all claims upon a basis of absolute equity, without regard to objections of a technical nature, or of the provisions of local legislation." 9 RIAA 115.

${ }^{117}$ Ibid. 444.

118 RIAA 1819.

119 See MIYOSHI, supra n. 100 at 165.

${ }^{120}$ Art. 3 (ii) of the Agreement of 30 June 1965, 17 RIAA 8.

${ }^{121}$ Ibid. 11. 
ritory) were awarded to Pakistan for considerations of peace and stability. The opinion of the chairman states:

\begin{abstract}
"In my opinion it would be inequitable to recognise these inlets as foreign territory. It would be conducive to friction and conflict. The paramount consideration of promoting peace and stability in this region compels the recognition and confirmation that this territory, which is wholly surrounded by Pakistan territory, also be regarded as such." ${ }^{122}$
\end{abstract}

This consideration is highly political, and therefore extra-legal, in nature, and would go beyond the bounds of equity as part of law. It could thus be considered to be a decision ex aequo et bono which the tribunal categorically denied in its preliminary finding.

There are some other territorial and boundary arbitrations in which a consideration of compromise was given. In the otherwise strictly legalistic award of the Beagle Channel case of 1977, for example, an exceptional compromise decision was made:

"If therefore, as the Court thinks, Argentina . . obtained the whole of Patagonia north of the Dungeness-Andes line and east of the Cordillera of the Andes, it does not seem unreasonable to regard Chile as receiving in principle . . . the much smaller area between that line and Cape Horn . ..."123

The others include: the 1931 Aaroo Mountain case between Saudi Arabia and Yemen where the former made a full concession to the latter for a consideration of peace combined with a spirit of chivalry; the 1817 Bay of Passamaquoddy Islands case between Great Britain and the United States in which the arbitrators allegedly made diplomatic transactions; the 1914 DutchPortuguese Island of Timor case where consideration was given to avoiding undue advantage being obtained by one of the parties; the 1897 Manica Boundary case in which the arbitrator took into account the concession which Great Britain had made of granting a large area of territory in the north of the Zambezi to Portugal in compensation for what Portugal would lose in the Manica Plateau; and the 1961 Honduras-Nicaragua Boundary Demarcation case where the mixed commission devised an artificial line to reconcile the claims of the parties which both conformed to the treaty. ${ }^{124}$

On the whole, older arbitrations seem to have more examples of decisions ex aequo et bono. While in most of these cases the arvitrators were not directed to decide ex aequo et bono, they nevertheless wielded their discretion in deciding in that way. If the Permanent Court of International Justice and the International Court of Justice have never made a decision ex aequo et bono, it is because the parties have never consented to such a basis for decision. But as we

\footnotetext{
${ }^{122}$ Ibid. 571.

${ }^{123}$ Emphasis in original; 52 ILR 144 para. 46.

${ }^{124}$ For a more detailed discussion of each of these cases, see MIYOSHI, supra n. 100 at 166-70.
} 
have seen above, some judicial cases could substantially be suspected of having been decided by considerations ex aequo et bono.

Common to arbitration and judicial settlement in this connection seems to be the tribunal's consideration for the position of each of the parties, i.e. consideration to make its decision equitable and acceptable to them both. Here again a comment by FITZMAURICE may be quoted, on the importance of consideration for the litigant parties and especially the losing party:

\begin{abstract}
"States and parties in the international field - entities which are proud, sensitive, and always to some extent at the mercy of their own domestic public opinion - disposed also to be distrustful of legal procedures - need to be given the feeling that their arguments have been adequately considered and above all, understood - so that they have something to show for the risks they have taken in going to law." 125
\end{abstract}

Inasmuch as the primary function of either institution is to settle disputes, the satisfactoriness of a decision would be the pre-condition for the parties to accept and fulfil it. It is needless to say, however, that it does not mean to arrange an easy compromise.

\title{
5. CONCLUSIONS
}

We have seen above that, while there are differences in degree in the parties' control over the composition of the tribunal and the conduct of proceedings, arbitration and judicial settlement in recent territorial and boundary cases do not present marked differences in the basis of their decisions nor in their reasoning. This is not, of course, to deny that there are some characteristic arbitrations, such as the Rann of Kutch, the Taba Boundary and the Dubai/Sharjah Boundary cases, in which very careful consideration was given to the claims of the parties. In the Rann of Kutch case an exceptional attempt was made to show the draft text of the award to the parties for comment before its formal adoption. This arrangement is recorded in the 'Introductory Note' of the award, ${ }^{126}$ and implies that it was made with the consent of the parties. In the Taba case a chamber of three arbitrators was set up within the tribunal of five, so that they were allowed to have consultations with the agents of the parties for settlement. This was the first-ever attempt of its kind in any arbitration, although un-successful. The procedure was in fact expressly provided for in the compromis $^{127}$ on the basis of the consent of the parties. All these cases are exceptional, however. Most recent arbitrations on territorial and boundary cases

${ }^{125}$ G.G. FitzMAURICE, 'Hersch Lauterpacht and his attitude to the judicial function", 50 BYIL (1979) 11.

${ }^{126} 17$ RIAA 3.

${ }^{127}$ Art. 9 of the compromis of 11 September 1986, 20 RIAA 111. 
basically do not seem to be different from similar ICJ cases as far as the basis of their decisions and the reasoning of the decisions are concerned.

This notwithstanding, arbitration and judicial settlement exist side by side. The latter institution is not shunned any more as it once was, and is recently even struggling with an overload of pending cases. ${ }^{128}$ On the other hand, the United Nations General Assembly has moved to adopt a resolution granting the status of permanent observer to the Permanent Court of Arbitration. ${ }^{129}$ Coupled with its own adoption of the Optional Rules for Arbitrating Disputes between Two States in October 1992, ${ }^{130}$ the Permanent Court of Arbitration may hopefully be re-activated. Also noteworthy is the establishment of the International Tribunal for the Law of the Sea, the members of which have recently been elected, with specialized functions as specified in the United Nations Convention on the Law of the Sea of 1982.

There is no doubt that such diversification of international adjudicative organs is a reflection of the will of states. It is a welcome trend for the promotion of peaceful settlement of international disputes. But since the basic attitude of states remains inclined to have as much control over the process of dispute settlement as possible, ${ }^{131}$ there is not much ground for optimism that they will actually respond favourably to this trend of diversification of adjudicative bodies. $^{132}$

\footnotetext{
${ }^{128}$ See e.g. the report of the Study Group of the British Institute of International and Comparative Law, supra n. 6.

${ }^{129}$ UNGA Resolution 48/3, 13 October 1993. A commentator stated that the move reflects the attitude of states to support the existence of the Permanent Court of Arbitration in parallel with the International Court of Justice. S. ROSENNE, 'Some thoughts on international arbitration today', 27 Israel Law Review (1993) 458-459.

${ }^{130}$ PCA, supra n. 7.

${ }^{131}$ See MIYOSHI, supra n. 15.

${ }^{132}$ A notable critical comment on the proliferating adjudicative organs in the field of human rights protection is found in: W.M. REISMAN, 'Creating, adapting and designing dispute resolution mechanisms for the international protection of human rights", in Implications of the Proliferation of International Adjudicatory Bodies for Dispute Resolution (Proceedings of a Forum co-sponsored by the American Society of International Law and the Graduate Institute of International Studies, Geneva, Switzerland, May 13, 1995, reproduced in 9 ASIL Bulletin 8-14).
} 